\title{
Supervision of International Narcotics Syndicates Through the Role of the Police as a Community Policing in Dealing with Narcotics Trafficking
}

\author{
Zulkarnain $^{1 *} \quad$ Nikmah Rosidah ${ }^{2} \quad$ Heni Siswanto $^{2}$ \\ 1.Students of the Doctoral Study Program in Law, Universitas Lampung, Bandar Lampung, Indonesia \\ 2.Lecturer of Faculty of Law, Universitas Lampung, Bandar Lampung, Indonesia
}

International Seminar on Foreign Investment Law in Indonesia-Muhammadiyah University Metro-28 October 2021

\begin{abstract}
The problem facing the Indonesian nation at this time is the circulation of narcotics, the rise of international narcotics syndicates through drug dealers who distribute nakotika in Indonesia, causing a fairly complete process for the Indonesian state, The number of victims of narcotics addicts becomes a criminal complaint that must be resolved by the police. Perpetrators in the circulation, users and couriers in this narcotics crime is a part of an international narcotics syndicate in Indonesia to the detriment of the Indonesian people, Policing as the door of criminal justice needs to increase supervision to reduce narcotics crimes in the community. The results and discussion in this writing are 1.existing conditions through the role of the Police as a community policing in dealing with the circulation of narcotics. Many victims of narcotics in Indonesia, used as business objects (economy). Perpetrators in the circulation, users and couriers in this narcotics crime is a part of an international narcotics syndicate in Indonesia to the detriment of the Indonesian people. 2. it needs urgency to build the role of the Police as a community policing in dealing with narcotics trafficking The role of the Police in building the urgency of community policing in dealing with narcotics circulation by sorting out users with drug dealers, by forming a community policing in children who are targeted by drug dealers 3 . The Role of Police As a Community Policing In Dealing With Narcotics Circulation as Prevention of International Narcotics Syndicates is Solving problems in the circulation of narcotics against international narcotics syndicates here tries to apply the concept of community policing, which sees the main target targeted by dealers, namely children, so the number of drug users, namely children, then the police here position the child as a victim, by way of community policing.
\end{abstract}

Keywords: Surveillance, International Narcotics Syndicates, Through The Role Police, Community Policing. DOI: $10.7176 / J L P G / 115-07$

Publication date: November $30^{\text {th }} 2021$

\section{Introduction}

Many criminal problems occur in Indonesia, not only in Indonesia, but also in the world, that is the role of law is needed in solving these criminal problems, Many problems about narcotics including crime or in law called a criminal act, the problem of crime is classified into criminal law, Criminal law is a law that regulates crimes that are useful to prevent and solve criminal crimes. ${ }^{1}$ The problem of narcotics is a crime that is very complicated for its resolution, because the number of users can be said to be the perpetrators of crimes and drug users are also carried out criminal action proceedings that get criminal sanctions for the perpetrator, While the user is a victim of a narcotics syndicate that has developed as an international crime.

The process of applying criminal law is carried out to solve the problem of crimes in the country of Indonesia, so that the community gets its rights as victims of criminal crimes, because people who are victims of criminal crimes have received suffering that befalls the victims, namely victims of the life and property of victims of the crime.

The problem facing the Indonesian nation at this time is the circulation of narcotics, judging from the juridical aspect is legitimate existence. This regulation only prohibits the use of narcotics without permission by law. This situation is often abused and not for the benefit of health but more than that, It is used as an object of business (economics). Perpetrators in the circulation, users and couriers in this narcotics crime is a part of an international narcotics syndicate in Indonesia to the detriment of the Indonesian people.

In Prevention giving the criminal itself is a matter of life but does not intend to degrade human dignity or suffer in question. ${ }^{2}$ This means that in the handling of crimes committed by children does not necessarily only apply embalming, but must pay attention to the survival of the child.

\footnotetext{
${ }^{1}$ Barda Nawawi Arief, Kebijakan Legislatif Dalam Penanggulangan Kejahatan Dengan Pidana Penjara (Semarang: Universitas Diponegoro, 1994).p.41.

${ }^{2}$ Wirjono Prodjodikoro, Tindak Pidana Tertentu Di Indonesia (Jakarta: P.T Erescohlm, 1980). p.3.
} 
Handling in tackling the abuse of distribution, drug testing carried out by children that are increasingly widespread is considered very important in protecting children in the community, considering the health of children's lives in the community is very important for the future sustainability of children. The number of drug users in Indonesia makes this country a target for illicit drug trafficking. ${ }^{1}$ This is due to the lack of awareness and curiosity of each child, so that from this feeling of causing bad habits for children, it is seen that the target of the circulation of narcotics is children, Thus the police need to think about the concept of prevention in cutting off the circulation of narcotics against narcotics syndicates through breaking the narcotics processing by forming a policy concept towards the circulation of narcotics through children.

There are several regulations that still weigh that a person who is said to be a drug user is given consideration as a victim of narcotics for example Law No. 11 of 2012 concerning the Juvenile Criminal Justice System, Because children are targeted for drug dealers as a destination for the circulation of narcotics by international narcotics syndicates, for that example, it can be said that there are drug users who have been criminal offenders in criminal law can be categorized as victims of narcotics crimes, then here justice becomes a material that must be considered with a restorative justice model.

In addition, in its development, efforts made by law enforcement officials in addition to restorative justice, also carried out rehabilitation efforts against children as perpetrators of narcotics crimes. Rehabilitation is basically organized to restore good habits for children of perpetrators as well as drug users, in order to run a life as usual. So that in everyday activities children can socialized again to the community and not dependence on drugs.

The circulation of narcotics that have been increasingly circulating in the country of Indonesia must also be resolved slowly. The concept of settlement must always be done with a new solution model, so here the role of the police must be sophisticated, with community policing methods trying to help solve the problem of narcotics that has become an international issue. Community policing is a method in community policing that is filtering drug abusers to break the chain of narcotics circulation by international narcotics syndicates, this method also uses restorative justice and whistle blower methods in breaking the chain of international narcotics syndicates.

During this process with restorative justice can be done healing narcotics users by means of rehabilitation, so that the drug user can get his right to recover from narcotics dependence as in article 127 of Law No. 35 of 2009 on Narcotics. Article 127 That narcotics abuse will be threatened with imprisonment and drug addicts can be said to be victims can be done social rehabilitation, but after the drug addict recovered can still be feared if still targeted by drug dealers.

Drug addicts are victims of drug abuse, with rehabilitation is an appropriate step in the countermeasures of criminal acts, because as victims of crime must be compensated by restoring the health of victims of narcotics crimes as victims of international narcotics syndicate crimes. Health in exchange for these losses is a form of justice for victims of narcotics crimes.

The circulation of narcotics an extraordinary crime in Indonesia can be seen from rehabilitation data in 2019 to 2020, the National Narcotics Agency has carried out rehabilitation of 13,320 who should target the implementation of rehabilitation for as many as 10,300 people, with details of 11,370 people with outpatient rehabilitation services. and 1,950 people hospitalized. Of these who follow post-rehabilitation services as many as 3,404 people. ${ }^{2}$ With the sake of disease it can be seen that rehabilitation of perpetrators is quite high and provides an opportunity to restore the attitude of people as drug offenders and users.

The police is the gateway to the settlement of criminal cases, for that the role of the police is very important for the settlement of narcotics circulation that has become an international illegal trade against international narcotics syndicates. The spread of narcotics has become more widespread with high enough rehabilitation data, so it is necessary to make great efforts in solving the circulation of these narcotics. As we know

The State Police of the Republic of Indonesia must be able to carefully control the settlement of narcotics crimes by seeing and paying attention to victims and perpetrators, with victims must also get their rights by means of rehabilitation through restorative justice and diversion methods, and also to overcome the crime of narcotics circulation by means of whistle blower methods, Thus the three methods can be united, and here with the application of Community Policing. The role of Community Policing is used by the police where the police are a part of the government that has law enforcement duties in the form of supervision and prevention and law enforcement against criminal acts as law No. 2 of 2002 concerning the State Police of the Republic of Indonesia. The police have clearly had a great responsibility in efforts to reduce criminal acts and prevent narcotics trafficking from international narcotics syndicates. ${ }^{3}$

The police force is part of the state government, which serves as a tool of law enforcement in law

\footnotetext{
${ }^{1}$ Wagiati Soetedjo, Hukum Pidanan Anak (Bandung: Refika Aditama, 2013). p.49.

2 'Sepanjang 2019, BNN Rehabilitasi 13.320 Orang | Merdeka.Com'<https://www.merdeka.com/peristiwa/sepanjang-2019-bnn-rehabilitasi13320-orang.html $>$ [accessed 26 September 2021].

${ }^{3}$ Nofta Wulan Sari, Winarti, and Joko Suranto, 'Peranan Bhayangkara Pembina Keamanan Dan Ketertiban Masyarakat Dalam Meningkatkan Pelayanan Keamanan Masyarakat Di Polsek Sumoroto Kabupaten Ponorogo', Transformasi, II.29 (2016), 56-159.
} 
enforcement and creates public order as the spearhead of the implementation of criminal settlement, not only by carrying out the criminal justice process but also by preventing criminal crimes from reducing the crime, and must be a commitment in himself and in the conscience of every member of the Police, so that members of the Police in carrying out their duties, functions and police authority can be better than before. Thus the concept of good police is realized as a prerequisite towards good-governance.

In the past ABRI and the Police are still in the same level, currently ABRI and the police have separate authorities, then the duty of the police has the authority of the civil government that is in terms of maintaining and maintaining order to create the task of prevention of criminal acts, through its duty, the police create a community police to handle criminal cases, which in this study is a criminal act of supervision of the prevention of victims of narcotics crimes from international narcotics syndicates.

The role of the community police aims to establish cooperation with the community and help the community to be more quickly resolved in the community, then against the control of narcotics crimes that have been growing in this Country of Indonesia, then with the community police more have the right capacity in the community by building the distribution of narcotics crimes.

Based on the decree of the Police Chief No. Pol: SKEP/737/X/2005 dated October 15, 2005 concerning the Policy and Strategy of The Implementation of The Community Policing Model in the implementation of police duties to be the right step in the police to implement faster prevention for the supervision and prevention of narcotics circulation both domestically, as well as from international syndicates. The guidelines of the police regulation are also accompanied by No. 7 of 2008 on Basic Guidelines for Strategy and Implementation of Community Policing in the Implementation of Police Duties and re-heard with Perkap No. 3 of 2015 on Community Policing (Polmas) which aims to create order in the community as well as the settlement of criminal abuses in the community.

Basically Polmas is a partnership performance in problem solving, namely by means of cooperation between the community and the police. When viewed from the science of philosophy, that Polmas or community policing by making a partner community for the resolution of criminal problems and preventing criminal problems, so by solving the narcotics problem by applying this policing communiting, which is to unite diversion methods, restorative justice and whistle blower by cooperating with the community for the maintenance of Kamtibmas; strive for the development of the existing Polmas system adapted to the development of the community and local cultural values. ${ }^{1}$

Prevention and countermeasures carried out by the Police in this case require further steps in the law enforcement process against drug trafficking criminals. The realization of the eradication of drug trafficking crimes cannot be separated from the role of law enforcement officials only, The need for cooperation from various parties, among others, is the participation of the community. And in making legal efforts against law enforcement does not have to commit criminal charges against perpetrators, but Can make various efforts. In the criminal law committed by children applied the concept of diversion but not covered from the renewal of criminal law in the concept of restorative justice. Judicial process is a law enforcement with the imposition of criminal sanctions for someone who commits a crime, in line with the role of the judge, it is also for the police as the leading door in the criminal justice process, It is necessary to consider and make policies against drug addicts who are also in Indonesia often subject to criminal justice proceedings, and there is criminal renewal in Indonesia filtering the application of a good criminal settlement process and providing a deterrent effect on criminal offenders. ${ }^{2}$

Efforts to prevent narcotics crimes committed by non-penal means will have more preventive properties. So that the main target of handling is about the factors that cause crime. ${ }^{3}$ These factors are aimed at the social conditions that occur in children as victims in narcotics crimes. Non-penal policy can be carried out by community policing as an effort to enforce criminal law in Indonesia.

Criminal settlement outside the non-criminal court policy is the right application for the settlement of crimes that are quite complicated, by screening perpetrators and victims, do not take the wrong steps of criminal settlement without determining the perpetrators and victims related to narcotics crimes. Because there are conducive factors in it. ${ }^{4}$ Non-penal settlement in criminal acts is a step to prevent criminal acts, then through non-penal can be done the method of applying whistle blower to find out the real drug trafficking perpetrators, Therefore, here the role of the police as a supervisor in the entry of international narcotics syndicates, thus, viewed from the point of criminal politics macro and globally, nonpenal efforts occupy the key and strategic

\footnotetext{
${ }^{1}$ Fakultas Hukum and Universitas Muria, “ ' Optimalisasi Peran Forum Kemitraan Polisi - Masyarakat ( FKPM ) Sebagai Alternatif Model Penyelesaian Tindak Pidana Ringan Di Luar Pengadilan ”,, 2012, 1-60.

2 E.Y. Kanter dan S.R. Sianturi, Asas-Asas Hukum Pidana Di Indonesia Dan Penerapannya (Jakarta: Storia Grafika, 2002).p. 59

${ }^{3}$ Barda Nawawi Arief, Beberapa Aspek Kebijakan Penegakan Dan Pengembangan Hukum Pidana (Bandung: PT. Citra Aditya Bakti, 1998). p. 102.

${ }^{4}$ Barda Nawawi Arief, Masalah Penegakan Hukum Dan Kebijakan Hukum Pidana Dalam Penanggulangan Kejahatan, Revisi (Jakarta: Prenada Media Grup, 2008). p. 39-40
} 
positions of the overall criminal political effort.

In addition to restorative justice, in the discussion of Community Policing also uses the whistle blower method used, namely the number of targets of children in drug distribution, then after the children are carried out restorative justice methods, it can be a whistle blower that is Article 1 Paragraph (4) of Law No. 31 of 2014 on Amendments to Law No. 13 of 2006 A whistle blower is someone who tells people who have legal authority that is information on criminal problems that will occur, are ongoing, or have occurred. ${ }^{1}$

Thus in law enforcement efforts by community policing, the effort that can be done is preventive efforts, meaning community policing in this case the police make preventive efforts so that there are no narcotics crimes and break the problem of narcotics distribution by international narcotics syndicates.

Based on the description, efforts that can be made by the police not only as supervision from the office where they work, but directly to the community. This means that the task of the police is not only as coordination with village officials in conducting prevention and supervision, the police must provide direct supervision. In order to prevent narcotics crimes committed by children can be minimized, thus the duty of the police in this case Polmas (community policing) as law enforcement can run well.

\section{Research Method}

The research in this writing uses normative juridical research and empirical juridical. Normative juridical research looks at existing documents and legislation in the settlement and settlement process using Community Policing,Regulation. Empirical Juridical research by looking at and presenting with the data that appears is rehabilitation data on drug victims. ${ }^{2}$ Therefore, this research is further referred to as Sociological Legal Research. ${ }^{3}$ This study combines the reality of rehabilitation data as the number of drug addicts as victims of drug trafficking crimes by international narcotics syndicates.

\section{Discussion}

A. existing conditions through the role of the Police as a community policing in dealing with the circulation of narcotics

The problem facing the Indonesian nation at this time is the circulation of narcotics, judging from the juridical aspect is legitimate existence. This regulation only prohibits the use of narcotics without permission by law. This situation is often misused and not for the benefit of health but more than that, which is used as an object of business (economy). Perpetrators in the circulation, users and couriers in this narcotics crime is a part of an international narcotics syndicate in Indonesia to the detriment of the Indonesian people.

In Prevention giving the criminal itself is a matter of life but does not intend to degrade human dignity or suffer in question. ${ }^{4}$ This means that in the handling of crimes committed by children does not necessarily only apply embalming, but must pay attention to the survival of the child.

Handling in tackling the abuse of distribution, drug testing carried out by children that are increasingly widespread is considered very important in protecting children in the community, considering the health of children's lives in the community is very important for the future sustainability of children. The number of drug users in Indonesia makes this country a target for illicit drug trafficking. ${ }^{5}$ This is due to the lack of awareness and curiosity of each child, so that from this feeling of causing bad habits for children, it is seen that the target of the circulation of narcotics is children, Thus the police need to think about the concept of prevention in cutting off the circulation of narcotics against narcotics syndicates through breaking the narcotics processing by forming a policy concept towards the circulation of narcotics through children.

A total of 87 million children aged a maximum of 18 years recorded 5.9 million exposed as drug addicts, 27 percent of whom are children, namely 1.6 million children as dealers, the data is considered KPAI quite alarming. Moreover, there is a tendency for cities to continue to target children as users or couriers. "There are 2,218 cases of children involved in this drug. Among them 15.69 percent of cases were as users and cases of dealers 8.1 percent of cases. ${ }^{6}$

According to Lawrence Meir Friedman the theory of the legal system is divided into ${ }^{7}$ : Legal Structure, Legal Substance, and Legal Culture (Legal Impact). The substance of the law is a guideline for the successful enforcement of the law, taking into account the factors that exist in Indonesian society to prevent narcotics crimes by international narcotics syndicates. ${ }^{8}$ Law enforcement may also consider the new substance as a legal

\footnotetext{
${ }^{1}$ Adhalia Septia Saputri and others, 'Juridical Implication of Overlapping Legal Protection for Whistleblowers in Narcotics Case in Indonesia', 79.26 (2018), 235-40

${ }^{2}$ Bambang Sunggono, Penelitian Hukum (Jakarta: PT Raja Grafindo Persada, 2003). Hl. 43.

${ }^{3}$ Soerjono Soekanto, Pengantar Penelitian Hukum (Jakarta: UI Press). p.51.

${ }^{4}$ Wirjono Prodjodikoro. p.3.

${ }^{5}$ Soetedjo. p. 49

${ }^{6}$ Ninla Elmawati Falabiba, ‘済無 No Title No Title No Title', 2019, 1-22.

${ }^{7}$ Lawrence M.Friedman, American Law (New York: Norton \& Company, 1984). p. 5-7

${ }^{8}$ M.Friedman. p. $15-18$
} 
product that can be implemented against the completion of criminal acts as a new rule. ${ }^{1}$

Substance also includes living law, not just the rules in the law books. As a country that still adheres to the Civil Law System or continental European system (although some laws and regulations have also adhered to the Common Law System or Anglo Sexon) ${ }^{2}$. It is said that the law is the written rules while the unwritten rules are not declared law. This system affects the legal system in Indonesia. ${ }^{3}$ Screening of a settlement is influenced by the principle of legality is also one in the Criminal Code. The new rules can be implemented combined with the principle of legality, where the law can be implemented, if there is a law that regulates it. ${ }^{4}$

B. urgency to build the role of the Police as a community policing in dealing with the circulation of narcotics The circulation of narcotics in Indonesia has been increasingly high, it is also the number of narcotics syndicates in the country of Indonesia, narcotics syndicates themselves are an international syndicate that has spread around the world. In Indonesia many international narcotics syndicates have been caught. ${ }^{5}$

Narcotics syndicates cooperate with drug dealers in a region, namely the Indonesian state by spreading to children in Indonesia, so that many children who use narcotics, where the law in Indonesia states that anyone who curses narcotics is also against the law, the targets of drug dealers are mostly children, so that children are entangled with narcotics, actually children are victims of international narcotics syndicates.

The law in its sense is not only limited to the regulations in writing, but the existing order of society, the order needs to be considered, so that the problems that will appear will be resolved by law enforcement. ${ }^{6}$ The law has a written law commonly called legislation and unwritten laws that grow in society. ${ }^{7}$ Violations of the regulations in writing will be subject to sanctions, and if violations committed according to the community are not in the laws and regulations, then it cannot be sanctioned, it is influenced by the principle of legality. ${ }^{8}$

According to Barda Nawawi Arief, the law enforcement process can be completed with the system of enforcement system that is from the substance legal structure, legal culture. ${ }^{9}$ Law enforcement has two meanings, namely thorough outside criminal justice, the second is in prose justice.

The role of the Police in building the urgency of community policing in dealing with the circulation of narcotics by sorting users with drug dealers, by forming community policing in children who are targeted by drug dealers, because through children it is easier for the dealer to be able to spread the narcotics, then the role of the police in building community policing is to position children who have known drugs to invite good communication to improve child cyclical and as a way to break the chain of drug distribution in international syndicates.

C. The Role of The Police as a Community Policing In Dealing With Narcotics Circulation as a Prevention of International Narcotics Syndicates

The circulation of narcotics as an illegal circulation by international narcotics syndicates has been difficult to overcome, therefore the police must be careful and use the right law in solving the problem of narcotics circulation.

Solving problems in the circulation of narcotics against international narcotics syndicates here tries to apply the concept of community policing, which sees the main target targeted by dealers, namely children, namely children, So the police here position the child as a victim, by way of community policing is an attempt to complete the completion of complicated criminal acts, and there are more and more victims such as narcotics crimes. Community policing departs from adagium that the police cannot alone control crime and offenses and improve people's quality of life. ${ }^{10}$

Community policing is an effort to build relationships in the settlement of criminal settlements that appear in many communities, and aims to reduce criminal crimes that arise in the community, so that the community does not feel afraid of the rise of criminals that arise. and also to break the chain of dieding also combines with

\footnotetext{
${ }^{1}$ Emy Hajar Abra, 'Sebuah Negara', III.2 (2016), 264-73.

${ }^{2}$ A. Widiada Gunakaya, 'KEDUDUKAN “LEX NE SCRIPTA” DALAM SISTEM HUKUM INDONESIA', Jurnal Wawasan Yuridika, 22.1 (2014), 1-29<http://ejournal.sthb.ac.id/index.php/jwy/article/view/1> [accessed 26 September 2021].

${ }^{3}$ Zaka Firma Aditya, 'Romantisme Sistem Hukum Di Indonesia: Kajian Atas Konstribusi Hukum Adat Dan Hukum Islam Terhadap Pembangunan Hukum Di Indonesia', Jurnal Rechts Vinding: Media Pembinaan Hukum Nasional, 8.1 (2019), 37 $<$ https://doi.org/10.33331/rechtsvinding.v8i1.305>.

${ }^{4}$ Peter de Cruz, Perbandingan Sistem Hukum Common Law, Civil Law, and Socialist Law (Bandung: Nusa Media, 2010 ). p.46

5 'Selundupkan $1 \mathrm{Kg}$ Sabu Dalam Map, Sindikat Narkoba Internasional Asal Afsel Diringkus - News Liputan6.Com' $<$ https://www.liputan6.com/news/read/4613767/selundupkan-1-kg-sabu-dalam-map-sindikat-narkoba-internasional-asal-afsel-diringkus> [accessed 26 September 2021].

${ }^{6}$ Gunakaya.

${ }^{7}$ Aditya.

${ }^{8}$ Peter de Cruz.

${ }^{9}$ Bunga Rampai Kebijakan Hukum Pidana. p. 30

${ }^{10}$ and Chuck Wexler Cordner, Gary W, Craig B.Fraser, Research Planning and Implementation"Local Government Police Management", 3d edn (Washington DC: International City Management Association, 1991). p. 346-347.
} 
Satjipto Rahardjo that the Theory of Restorative Justice is a progressive legal point of view not to assume in the legalistic-dogmatic, analytically positivism direction, but rather to sociological. ${ }^{1}$ Laws are not always guided by positive laws or laws alone, but they can also be guided and looked at on a non-formal principle. Restorative Justice is a "response to a victim-centered crime that allows victims, criminal offenders, their families, and representatives from the community to deal with the damage and harm caused by criminal acts. ${ }^{2} \mathrm{~A}$ whistleblower in a narcotics case can come from the community or a victim of a narcotics crime, where the whistleblower helps uncover a narcotics crime. Every citizen and victim of a narcotics crime who becomes

The whistle-blower is to have protection for his safety, the safety of his family, and for his assets, and that is to ensure that the person will notify the police so that he feels protected from physical or psychological threats regarding this case. Both of these are carried out in different ways, namely in a unity of community policing forms that are to achieve the termination of the narcotics circulation chain that has international standards. ${ }^{3}$

\section{Conclusion}

Existing conditions through the role of the Police as a community policing in dealing with the circulation of narcotics from the juridical aspect is legitimate existence. This regulation only prohibits the use of narcotics without permission by law. This situation is often misused and not for the benefit of health but more than that, which is used as an object of business (economy). Perpetrators in the circulation, users and couriers in this narcotics crime is a part of an international narcotics syndicate in Indonesia to the detriment of the Indonesian people.

Urgency to build the role of the Police as a community policing in dealing with narcotics circulation The role of the Police in building the urgency of community policing in dealing with the circulation of narcotics by sorting users with drug dealers, by forming community policing in children who are targeted by drug dealers, because through children it is easier for the dealer to be able to spread the narcotics, So the role of the police in building community policing is to position children who have had time to know drugs to invite good communication to improve child cyclical and as a way to break the chain of drug distribution in international syndicates.

The Role of Police as Community Policing In Dealing With Narcotics Circulation As Prevention of International Narcotics Syndicates is Solving problems in the circulation of narcotics against international narcotics syndicates here trying to apply the concept of community policing, which sees the main target targeted by dealers, namely children, then the number of drug users, namely children, So the police here position the child as a victim, by means of community policing is a collaborative effort between the police and the community that identifies the problem of violations and crimes by involving all elements of the community to find a solution to the problem. Community policing departs from the adagium that the police cannot alone control crime and misconduct and improve people's quality of life.

\section{Reference}

Abra, Emy Hajar, 'Sebuah Negara', III.2 (2016), 264-73

Aditya, Zaka Firma, 'Romantisme Sistem Hukum Di Indonesia: Kajian Atas Konstribusi Hukum Adat Dan Hukum Islam Terhadap Pembangunan Hukum Di Indonesia', Jurnal Rechts Vinding: Media Pembinaan Hukum Nasional, 8.1 (2019), 37 <https://doi.org/10.33331/rechtsvinding.v8i1.305>

Arief, Barda Nawawi, Beberapa Aspek Kebijakan Penegakan Dan Pengembangan Hukum Pidana (Bandung: PT. Citra Aditya Bakti, 1998)

- Kebijakan Legislatif Dalam Penanggulangan Kejahatan Dengan Pidana Penjara (Semarang: Universitas Diponegoro, 1994)

_- Masalah Penegakan Hukum Dan Kebijakan Hukum Pidana Dalam Penanggulangan Kejahatan, Revisi (Jakarta: Prenada Media Grup, 2008)

Article 5 of Law Number 31 of 2014 Concerning Protection for Witnesses and Victims

Bunga Rampai Kebijakan Hukum Pidana (Jakarta: Kencana Prenada Media Group, 2010)

Cordner, Gary W, Craig B.Fraser, and Chuck Wexler, Research Planning and Implementation"Local Government Police Management", 3d edn (Washington DC: International City Management Association, 1991)

Gunakaya, A. Widiada, 'KEDUDUKAN "LEX NE SCRIPTA” DALAM SISTEM HUKUM INDONESIA', Jurnal Wawasan Yuridika, 22.1 (2014), 1-29 <http://ejournal.sthb.ac.id/index.php/jwy/article/view/1> [accessed 26 September 2021]

Hukum, Fakultas, and Universitas Muria, “" Optimalisasi Peran Forum Kemitraan Polisi - Masyarakat ( FKPM ) Sebagai Alternatif Model Penyelesaian Tindak Pidana Ringan Di Luar Pengadilan ”, 2012, 1-60

\footnotetext{
${ }^{1}$ Satjipto Rahardjo, Penegakan Hukum Progresif (Jakarta: Kompas Media Nusantara, 2010). Hlm34.

2 and Struart Henry Mark, M. Lenier, Essential Criminology, second (USA: Westview colorado, 2004). p. 332-400.

${ }^{3}$ Article 5 of Law Number 31 of 2014 Concerning Protection for Witnesses and Victims.
} 
M.Friedman, Lawrence, American Law (New York: Norton \& Company, 1984)

Mark, M. Lenier, and Struart Henry, Essential Criminology, second (USA: Westview colorado, 2004)

Meliala, A, 'Peran Polisi Wanita Dalam Polmas Berbasis Gender', Jurnal Ilmu Kepolisian, 14 (2020), 158-69 $<$ http://www.jurnalptik.id/index.php/JIK/article/view/269>

Ninla Elmawati Falabiba, '済無No Title No Title No Title', 2019, 1-22

Peter de Cruz, Perbandingan Sistem Hukum Common Law, Civil Law, and Socialist Law (Bandung: Nusa Media, 2010)

Saputri, Adhalia Septia, Moch Bakri, Prija Djatmika, and Suharyono Ar, 'Juridical Implication of Overlapping Legal Protection for Whistleblowers in Narcotics Case in Indonesia', 79.26 (2018), 235-40

Sari, Nofta Wulan, Winarti, and Joko Suranto, 'Peranan Bhayangkara Pembina Keamanan Dan Ketertiban Masyarakat Dalam Meningkatkan Pelayanan Keamanan Masyarakat Di Polsek Sumoroto Kabupaten Ponorogo', Transformasi, II.29 (2016), 56-159

Satjipto Rahardjo, Penegakan Hukum Progresif(Jakarta: Kompas Media Nusantara, 2010)

'Selundupkan $1 \mathrm{Kg}$ Sabu Dalam Map, Sindikat Narkoba Internasional Asal Afsel Diringkus - News Liputan6.Com' <https://www.liputan6.com/news/read/4613767/selundupkan-1-kg-sabu-dalam-mapsindikat-narkoba-internasional-asal-afsel-diringkus $>$ [accessed 26 September 2021]

'Sepanjang 2019, BNN Rehabilitasi 13.320 Orang | Merdeka.Com' $<$ https://www.merdeka.com/peristiwa/sepanjang-2019-bnn-rehabilitasi-13320-orang.html $>$ [accessed 26 September 2021]

Sianturi, E.Y. Kanter dan S.R., Asas-Asas Hukum Pidana Di Indonesia Dan Penerapannya (Jakarta: Storia Grafika, 2002)

Soekanto, Soerjono, Pengantar Penelitian Hukum (Jakarta: UI Press)

Soetedjo, Wagiati, Hukum Pidanan Anak (Bandung: Refika Aditama, 2013)

Sunggono, Bambang, Penelitian Hukum (Jakarta: PT Raja Grafindo Persada, 2003)

Wirjono Prodjodikoro, Tindak Pidana Tertentu Di Indonesia (Jakarta: P.T Erescohlm, 1980) 